\title{
The Relationship between Demographic Factors and Adjustment to University for Mature-Age, Undergraduate Students
}

\author{
Merryn Dawborn-Gundlach \\ Melbourne Graduate School of Education \\ The University of Melbourne \\ Australia
}

\begin{abstract}
It is important that all students who enrol in tertiary institutions can complete their chosen course. A smooth transition is critical in ensuring that the initial experience of university is positive and that students adjust well to the academic, social and personal demands of tertiary study. Some issues of adjustment affect all first-year students, while some are specific to certain demographic groups. Older students may have extra responsibilities and demands on their time, which can have a negative impact on their university adjustment. The experience of transition and ultimate adjustment of 'non-school leavers' or 'mature-age students', those who do not enter university directly from school are relatively unexplored in the existing academic literature. This article reports the specific findings of a broader study involving the transition and adjustment of mature-age, undergraduate students to university (Dawborn-Gundlach, 2015). As part of this study an online survey questionnaire sought information regarding participant adjustment to university according to four scales and ten subscales of adjustment (Baker \&Siryk, 1988,1999) and demographic groupings which included; gender, age group, first language spoken, nationality, previous education, family situation, enrolment category and employment details.The study highlights the differences between university adjustment for diverse demographic groups. Significant, positive associations were identified between students who spoke English as their first language and the scales of Social Adjustment, Personal Adjustment and Attachment and with a calculated Overall Index of Adjustment.
\end{abstract}

Keywords: transition; adjustment; mature-age students; measures of adjustment

\section{Introduction}

The student cohort entering university undergraduate courses both in Australia and internationally is changing demographically as greater numbers of international and mature-age students pursue tertiary education. Demographic diversity raises questions about the relevance of orientation programs and university services, the number and types of courses offered, the timing of lectures and tutorials and student retention. It is essential that all first-year students are supported through their transition and make a positive adjustment to university, so they can remain at university and achieve success in their enrolled undergraduate course.

The changing demographics of students commencing university in Australia has implications for the support and services required to ensure student experiences of tertiary study are both positive and achievable (Krause, Hartley, James, \& McInnis, 2005; Lee Dow, 2009). The specific requirements of all students must be considered in the development of inclusive orientation programs and support services, to ensure a positive transition is accessible to all first-year undergraduate students (Educational Transitions and Change Research Group, 2011) and in supporting the academic progress, personal adjustment, and social requirements of current and future students of all demographic groups (Hellsten, 2002; Ayres \& Guilfoyle, 2009). The needs of the increasing number of mature-age students commencing university must also be considered in providing appropriate support to ensure this group of students persists and succeeds in tertiary study (Lee Dow, 2009).

Students' early experiences of university can significantly affect their attitudes and self-confidence to continue their courses (McInnis \& James, 1995) and are critical in setting the tone and establishing patterns of learning (Tinto, 1995). The confidence required to navigate the academic, organisational, social and cultural aspects of tertiary study can be undermined if students encounter too many challenges in their university transition (Conley, 2007). 
Transition involves a move from one set of conditions or environment to another. Time spent in transition is dependent on factors such as the support provided by the institution, the personal and demographic characteristics of the individual, and the types of experiences and issues faced in the initial stages of the transition period (Darlaston-Jones, Cohen, Haunold, Pike, Young \& Drew, 2003). An effective transition and subsequent adjustment to the university environment has been shown to be associated with factors including age, family responsibilities, family support and financial commitments, student identity, enrolment category, employment and course enjoyment (Huon \& Sankey, 2000), student expectations (Pargetter, McInnis, James, Evans, Peel \& Dobson, 1998; Cook \& Leckey, 1999; Evans \& Peel, 1999; Huon \& Sankey, 2000; McInnis, Hartley, Polesel \& Teese, 2000), attitude and resilience (Kantanis, 2002) and students' social support networks (Buote, Pancer, Pratt, Adams, Birnie-Lefcovitch, Polivy \& Wintre, 2007; Ayres \& Guilfoyle, 2009).

Demographic factors such as age, gender, first language spoken, family situation and educational background are important indicators of a successful transition and adjustment to university but there are difficulties involved in separating the characteristics and treating them in isolation from each other. Older students are more likely to have families and/or dependents, while female students, in more traditional family situations, are more likely to be the primary carers for dependent children. While it is important to determine the association that each characteristic has on transition and adjustment, it must be noted that demographic characteristics are also interrelated (Evans, 2000; Cushman, 2004).

Students enrol in university with a range of individual characteristics which influence their motivation, persistence and level of involvement with the academic and social cultures of the institution (Tinto, 1975). Although personal characteristics such as motivation, resilience and self-confidence are difficult to measure, they are important factors in students' university adjustment. Age, gender and first language spoken are more easily determined and have also been demonstrated as factors of influence in university adjustment (Dawborn-Gundlach \& Margetts, 2018).

While mature-age students experience many of the same challenges as students who commence university directly from secondary school; they may also face additional issues. Mature-age students are more likely than schoolleaver students to have a partner, dependent children and/or ageing parents. The ability to manage competing demands on their time, including the extra responsibilities of family or dependents, can affect their available time on campus, their participation in campus-based activities and negatively impact their sense of belonging to the university (Kantanis, 2002; Cushman, 2004). This study determines the strength of associations between students' demographic characteristics and their university adjustment across four domains; academic, social and personal adjustment and student attachment to university, and with an overall measure of university adjustment.

\section{Literature Review}

University adjustment has been extensively researched internationally and within Australia (Evans\& Peel, 1999; Kantanis, 2000; Blunden, 2002; Krause et al., 2005; Tinto, 2005; Yau, Sun\& Cheng, 2012); however, studies focusing on the transition of students who commence their tertiary education at a later stage of their life, sometimes after a long break from their previous education, have been less frequently undertaken. The increasing number of mature-age students enrolling in universities worldwide (OECD, 2017), suggests that future studies of transition should include the experiences of these students.

The relationship between student adjustment and age has been researched primarily through a comparison of the academic performance of younger and older students (McInnis \& James, 1995; Richardson, 1995; Huon \& Sankey, 2000; Krause, et al., 2005); however, research findings from studies comparing the performance of older students with school-leaver students are inconclusive.

The effect of gender on university adjustment is difficult to determine in isolation of other factors. The traditional involvement of women in the role as primary caregiver has implications for their transition and adjustment to university as they juggle the conflicting demands of home and study (Newson, McDowell \& Sanders, 2011). To cover basic living costs, some students must work in paid employment. The number of hours spent working in paid employment while studying, can also have implications for students' ability to manage the workload and for their available time on campus, thus affecting both their persistence and adjustment at university (Huon \& Sankey, 2000), and their integration into the wider university life (Bird \& Morgan, 2003). 
The competing demands of family responsibilities and employment can similarly restrict the number of hours spent on campus and on required reading and assignments, subsequently affecting student engagement in both the academic and social culture of university life.

While Anderson, Benjamin and Fuss (1994) indicated that the mature-age students in their study achieved higher grades than the school-leaver students, mature-age students were also found to miss more classes due to their family responsibilities. Attendance at lectures and tutorials and completion of the required course work is difficult when undertaken in conjunction with family and other responsibilities. Study time can be either determined by residual family time or determine the time available to spend with family and friends.

Indications concerning student gender and a successful transition are inconclusive. Although Huon and Sankey (2000) reported that female students had a more positive transition than males, Gall et al., (2000) suggested that transition caused a greater strain for female students who were 'more vulnerable' in their initial transition. In a comparative study of female students, Carney-Crompton and Tan (2002) found that older female students, aged 35 years to 44 years, had higher academic performance than traditional female students aged 18 years to 22 years, thus suggesting a successful academic adjustment to university.

Students' first language is an important consideration in their adjustment to university affecting both their academic and social adjustment (Andrade, 2006). In an English-speaking university, students who did not speak English as their first language were found to have a less successful transition than students whose first language was English (McInnis \& James, 1995; Huon \& Sankey, 2000).

Studies involving international students have shown the negative effect of language on university adjustment. Aside from homesickness, forming social connections, lack of finances and language efficacy can be concerning for international students attempting to adjust to university. Students who do not confidently speak the language of instruction of the university have more difficulties in their understanding of the theory, leading to a reduction of self-confidence (Sherry, Thomas \& Chui, 2010) and ultimately affecting their personal adjustment to university (Yang, Noels \&Saumure, 2006).

Identification with broader aspects of university life, especially during the first few weeks, can positively enhance student attachment and commitment to university and overall university adjustment (Pargetter, et al., 1998). Participation is arguably more difficult for students with part-time enrolment, employment commitments and family responsibilities and has implications not only for meeting other students and making friends but also for creating an identity as a student (Huon \& Sankey, 2000). Adjustment to the university environment, engagement with the university culture and a sense of belonging or attachment are the tangible outcomes of a successful transition (Educational Transitions and Change Research Group, 2011).

\section{Methods}

An online survey questionnaire was utilised to identify students' adjustment to university. The survey included four scales and ten subscales of adjustment and personal background and demographic information about the participants. The collected data included intrinsic factors, such as age, gender, first language spoken and extrinsic factors such as employment details, family responsibilities and level of previous education.A five-point Likerttype response scale was used to measure student adjustment to university in relation to scales and subscales of Academic, Social, Personal Adjustment and Attachment. Based on a modified version of the American Student Adaptation to College Questionnaire (SACQ) (Baker \&Siryk, 1989, 1999), the survey was designed to assess the 'quality of the students' adjustment to - rather than an evaluation of - that environment' (p. 4).

The scale Academic Adjustment addresses the educational demands, attitudes, application to study, accomplishment and satisfaction with the academic environment as perceived by the students. The four subscales of Academic Adjustment (AA) are; Motivation (AAM), Application (AAA), Performance (AAP) and Environment (AAE).

The Social Adjustment scale is significant in terms of the interpersonal-societal demands on students and includes social functioning, involvement and relationships with other people, social and physical relocation and satisfaction with the social environment. The four subscales of Social Adjustment (SA) are; General (SAG), Other people (SAP), Nostalgia (SAN) and Environment (SAE). The Personal Adjustment scale, referred to by Baker and Siryk $(1989,1999)$ as the Personal-emotional Adjustment scale (PA),relates to student' well-being and includes the two subscales; Psychological (PAP) and Physical adjustment (PAPh). 
The Attachment scale (A) explores participant feelings about being at university in general and the institution they are attending, in particular (Baker \& Siryk, 1989, 1999). This scale consists of items relating to feeling part of the first-year cohort, fitting in, meeting people and satisfaction with university life, including the university social culture. The scale of Adjustment has no subscales.

\section{Participants}

Forty mature-age students participated in the study. Participation was invited through notices on the university student portal and mature-age students' Facebook page and by personal invitation at the inaugural meeting of the mature-age students' club. The initial component of the survey requested information relating to demographic characteristics of the participants which are summarised in Table 1.

Table 1 Survey participants' demographic groups

\begin{tabular}{|c|c|c|c|}
\hline Characteristic & Category & $\begin{array}{l}\text { Participant Numbers } \\
N=\mathbf{4 0}\end{array}$ & $\begin{array}{l}\text { Participant } \\
\text { Percentage }\end{array}$ \\
\hline \multirow[t]{2}{*}{ Gender } & Female & 25 & 62.5 \\
\hline & Male & 15 & 37.5 \\
\hline Permanent & International & 5 & 12.5 \\
\hline Residential address & Local & 35 & 87.5 \\
\hline \multirow[t]{2}{*}{ Age group } & $>40$ & 18 & 45.0 \\
\hline & $23-40$ & 22 & 55.0 \\
\hline \multirow[t]{2}{*}{ First language } & Other & 3 & 7.5 \\
\hline & English & 37 & 92.5 \\
\hline \multirow[t]{3}{*}{ Previous education } & $\begin{array}{l}\text { VCE, Australian } \\
\text { equivalent or TAFE }\end{array}$ & 17 & 42.5 \\
\hline & Other & 22 & 55.0 \\
\hline & Missing & 1 & 2.5 \\
\hline Year of & pre -2000 & 16 & 40.0 \\
\hline completion of & $2000-2010$ & 22 & 55.0 \\
\hline previous education & Missing & 2 & 5.0 \\
\hline \multirow[t]{3}{*}{ Family situation } & No dependents & 24 & 60.0 \\
\hline & Dependents & 15 & 37.5 \\
\hline & Missing & 1 & 2.5 \\
\hline Employment & No employment & 11 & 27.5 \\
\hline \multirow[t]{2}{*}{ Situation } & Employment & 28 & 70.0 \\
\hline & Missing & 1 & 2.5 \\
\hline \multirow[t]{3}{*}{ Enrolment category } & Part-time & 15 & 37.5 \\
\hline & Full-time & 24 & 60.0 \\
\hline & Missing & 1 & 2.5 \\
\hline \multirow{3}{*}{ Payment options } & Pays fees as due & 7 & 17.5 \\
\hline & Fee deferral (HECS) & 31 & 77.5 \\
\hline & Missing & 2 & 5.0 \\
\hline \multirow[t]{3}{*}{ Nationality } & Other & 4 & 10.0 \\
\hline & Australian & 29 & 72.5 \\
\hline & Missing & 7 & 17.5 \\
\hline \multirow[t]{3}{*}{ Enrolled course } & Other & 16 & 40.0 \\
\hline & Arts & 23 & 57.5 \\
\hline & Missing & 1 & 2.5 \\
\hline First preference & Yes & 34 & 85.0 \\
\hline \multirow[t]{2}{*}{ Offer } & No & 5 & 12.5 \\
\hline & Missing & 1 & 2.5 \\
\hline
\end{tabular}

Students are classified as mature-age at the participating university if they are 23 years of age or older. The modal age range of participants was 23 - 29 years. Eighteen participants were over the age of 40 (45\%), including ten participants who were over the age of $50(25 \%)$. 
Apart from one female participant who was aged over 70 years, the smallest group was aged between 30 and 39 years.Two of the four participants declaring 'other' nationalities were from the United Kingdom and spoke English as their first language. Three participants spoke English as their second language.

Although five participants (12.5\%) had completed the Victorian Certificate of Education (VCE), which is the traditional entry for school leaver students into universities in Victoria, 34 participants $(85 \%)$ entered university through an alternative entry pathway. Seven participants indicated they had completed their previous education in the years 1980-1989 and four participants in the period 1970-1979. This represents a possible 30-40 year break between academic studies for these participants, with implications for their transition to university and their academic expectations, research skills and study techniques.

Seventy percent of participants were employed in paid work; 24 in part-time employment and four in full-time employment. The combination of part-time employment and full-time enrolment was the most common, with 15 participants $(37.5 \%)$ reporting this situation. A further seven participants reported working and studying part-time while one participant combined full-time employment with full-time university enrolment. Five participants over 40 years of age were paying their fees as they were due, while two of the 22 participants in the $23-40$ year age groupwere paying their university fees as they were due. Thirty-one participants were deferring the payment of their university fees through the Higher Education Contribution Scheme (HECS) (77.5\%), 15 in the over 40-yearold age group and 16 in the younger age group. Twenty-one of the 25 female participants were using the fee deferral scheme, while ten of the fifteen male participants supported this option. Twenty-three participants were enrolled in a Bachelor of Arts course. The number of Arts enrolments comprised more than three times the number of participants enrolled in a Bachelor of Science (6) and five times more than in the Bachelor of Environments degree course (4). Thirty-four of the 40 participants accepted places in their first preference course.

\section{Results}

Participants rated their experiences of university adjustment using a five-point Likert-type scale with $1=$ strongly disagree, 2 = disagree, 3 = neither disagree or agree, $4=$ agree and $5=$ strongly agree.To identify relationships between demographic characteristics and adjustment to university, mean adjustment scores for the ten subscales were calculated by adding participant responses to each of the relevant subscale items to obtain a subscale score. Subscale scores were divided by 40 (the number of participants) to create a mean adjustment score for the group for each of the ten adjustment subscales.

\section{Demographic influences in the ten subscales of adjustment}

Mean adjustment subscale scores were differentiated by gender and age group, to investigate the relationship between the subscale scores and key demographic groupings. Table 2 presents the mean and percentage mean adjustment scores of the group on the ten subscales and differentiated scores, according to gender and age group. The maximum possible mean adjustment score on each subscale is provided in parenthesis.

Table 2Mean adjustment subscale scores and percentage mean adjustment scores for the whole group and differentiated according to gender and age group

\begin{tabular}{|c|c|c|c|c|c|c|c|c|c|c|c|}
\hline \multicolumn{2}{|l|}{ Scale } & \multicolumn{4}{|c|}{ Academic Adjustment (AA) } & \multicolumn{3}{|c|}{ Social Adjustment (SA) } & \multicolumn{3}{|c|}{ Personal Adjustment } \\
\hline Subscale & $\mathrm{n}$ & $\begin{array}{l}\text { AAM } \\
(10)\end{array}$ & $\begin{array}{l}\text { AAA } \\
\text { (4) }\end{array}$ & $\begin{array}{l}\text { AAP } \\
(14)\end{array}$ & $\begin{array}{l}\text { AAE } \\
\text { (14) }\end{array}$ & $\begin{array}{l}\text { SAG } \\
(14)\end{array}$ & $\begin{array}{l}\text { SAP } \\
(16)\end{array}$ & $\begin{array}{l}\text { SAN } \\
\text { (4) }\end{array}$ & $\begin{array}{l}\text { SAE } \\
(6)\end{array}$ & $\begin{array}{l}\text { PAPs } \\
\text { (16) }\end{array}$ & $\begin{array}{l}\text { PAPh } \\
\text { (6) }\end{array}$ \\
\hline Whole group 40 & & 8.8 & 3.7 & 7.3 & 11.8 & 6.9 & 7.1 & 2.8 & 2.6 & 11.6 & 3.5 \\
\hline Whole group $(\%$ & & 88.0 & 92.5 & 52.1 & 84.3 & 49.3 & 44.4 & 70.0 & 43.3 & 72.5 & 58.3 \\
\hline Gender & & & & & & & & & & & \\
\hline Female & 25 & 8.6 & 3.9 & 9.0 & 9.8 & 7.3 & 7.0 & 2.6 & 3.3 & 10.9 & 4.5 \\
\hline Female(\%) & & 86.0 & 97.5 & 64.3 & 70.0 & 52.1 & 43.8 & 65.0 & 55.0 & 68.1 & 75.0 \\
\hline Male & 15 & 9.1 & 3.5 & 9.1 & 10.2 & 5.8 & 6.6 & 2.6 & 3.1 & 11.3 & 4.4 \\
\hline Male $(\%)$ & & 91.0 & 87.5 & 65.0 & 72.9 & 41.4 & 41.3 & 65.0 & 51.7 & 70.6 & 73.3 \\
\hline Age group & & & & & & & & & & & 4.5 \\
\hline$>40$ & 18 & 8.6 & 3.9 & 8.8 & 10.6 & 7.1 & 7.1 & 2.4 & 2.9 & 11.4 & 4.7 \\
\hline$>40(\%)$ & & 86.0 & 97.5 & 62.9 & 75.7 & 50.7 & 44.4 & 60.0 & 48.3 & 71.3 & 78.3 \\
\hline $23-40$ & 22 & 9.1 & 3.5 & 10.1 & 8.7 & 6.8 & 6.5 & 2.7 & 3.4 & 10.8 & 4.5 \\
\hline $23-40(\%)$ & & 91.0 & 87.5 & 72.1 & 62.1 & 48.6 & 40.6 & 67.5 & 56.7 & 67.5 & 75.0 \\
\hline
\end{tabular}


Academic Adjustment;AAM Motivation, AAA Application, AAP Performance, AAE Environment, Social Adjustment; SAG General, SAP Other People, SAN Nostalgia, SAE Environment, Personal Adjustment; PAPs Psychological, PAPh Physical

Adjustment was stronger in the subscales of Academic Adjustment than for the subscales of Social and Personal Adjustment. The exception, Academic Performance (AAP) showed a lower percentage mean adjustment score $(52.1 \%)$.

Mean adjustment scores on Academic Application (AAA) were higher for the whole group and also when differentiated for age and gender, than for Academic Motivation (AAM), Environment (AAE) and Performance (AAP). The exceptions were for male students and students aged $23-40$ years, suggesting males and younger students had stronger motivation than other students.

Subscale scores within the Social Adjustment scale were generally lower than subscale scores in the Academic Adjustment scale. The highest mean scores were shown in the Nostalgia subscale (SAN), indicating that students were less concerned about social relocation and homesickness than other aspects of their Social Adjustment. This was also evident when the group was differentiated according to gender and age group. Percentage mean adjustment scores for the subscales; General (SAG), relating to the general social culture, Other People (SAP) and Environment (SAE) were reasonably consistent. Scores for these three subscales of Social Adjustment ranged from 40.6 percent to 56.7 percent. With Nostalgia included, the maximum value of the range increased to 70.0 percent agreement.

Mean scores in the subscales of the Personal Adjustment scale; Psychological (PAPs), concerning tension and stress, and Physical (PAPh), relating to sleep, health and life/university balance, revealed that as a group, Psychological Adjustment (PAPs) (72.5\%) was considerably higher than their Physical Adjustment (PAPh) $(58.3 \%)$.

Although male students had slightly higher mean adjustment scores on three of the four subscales of Academic Adjustment, independent samples t-tests did not reveal the differences between the scores of male and female students to be statistically significant. Similarly, no significant differences were identified between the subscale scores of male and female students within the Social Adjustment and Personal Adjustment scales.

In the scale of Academic Adjustment, older mature-age students showed higher scores on Application (AAA) and Environment (AAE) while students in the age group 23-40 years indicated higher mean adjustment scores on Motivation (AAM) and Performance (AAP). Adjustment scores were equally distributed in the Social Adjustment scale with older students showing higher scores on the subscales of General (SAG) and Other People (SAP). Students in the 23-40 years age group revealed higher scores on the Environment (SAE) and Nostalgia (SAN) subscales of Social Adjustment. Older students displayed higher adjustment scores on both the Psychological (PAPs) subscale and Physical subscale (PAPh) compared with students in the age range 23-40 years.

No notable differences were determined when the mean adjustment scores on the ten subscales were differentiated according to gender and age group; however, some trends were apparent. The scores on the subscales of Academic Adjustment were higher than scores on the Social and Personal Adjustment subscales, except for Academic Performance (AAP). Within the scale of Social Adjustment, the subscale; Other People (SAP) revealed consistently low mean adjustment scores across the whole group and when differentiated for gender and age group. The highest scores were shown in the subscale Academic Application (AAA) and lowest in the subscale Social Environment (SAE).

\section{Demographic influences in the four scales of adjustment}

Responses on items relating to each of the ten subscales presented in Table 2 were aggregated to create scale scores for Academic Adjustment, Social Adjustment and Personal Adjustment. The Attachment scale did not contain subscales. The aggregation allowed comparisons to be made between the adjustment of different personal and demographic groups within the scales of Academic, Social and Personal Adjustment. The calculation of subscale and scale adjustment scores enabled associations within and between the scales to be determined (Appendix 2), thus confirming the validity of the use of subscale scores in creating scale scores and an overall index of adjustment and enabling the identification of relationships between demographic groups and adjustment across each of the four scales (Table 3). 
Table 3Mean adjustment scale scores and mean adjustment scores for the whole group and differentiated according to demographic groups

\begin{tabular}{|c|c|c|c|c|c|c|c|c|c|}
\hline \multicolumn{2}{|l|}{ Scale } & \multicolumn{2}{|c|}{$\begin{array}{l}\text { Academic } \\
\text { Adjustment } \\
(32) \\
\end{array}$} & \multicolumn{2}{|c|}{$\begin{array}{l}\text { Social } \\
\text { Adjustment } \\
\text { (40) }\end{array}$} & \multicolumn{2}{|c|}{$\begin{array}{l}\text { Personal Adjustment } \\
\text { (22) }\end{array}$} & \multicolumn{2}{|c|}{$\begin{array}{l}\text { Attachmen } \\
\text { (22) }\end{array}$} \\
\hline Characteristic & $N$ & $M$ & $\%$ & $M$ & $\%$ & $M$ & $\%$ & $M$ & $\%$ \\
\hline Whole group & 40 & 22.8 & 71.3 & 19.3 & 48.3 & 15.7 & 71.4 & 14.6 & 66.4 \\
\hline \multicolumn{10}{|l|}{ Gender } \\
\hline Female & 25 & 22.7 & 70.9 & 20.1 & 50.3 & 15.6 & 70.9 & 14.8 & 67.3 \\
\hline Male & 15 & 22.8 & 71.3 & 18.1 & 45.3 & 15.9 & 72.3 & 14.4 & 65.5 \\
\hline \multicolumn{10}{|l|}{ Age group } \\
\hline$>40$ & 18 & 23.3 & 72.8 & 19.3 & 48.3 & 16.2 & 73.6 & 15.5 & 70.5 \\
\hline $23-40$ & 22 & 22.3 & 69.7 & 19.4 & 48.5 & 15.3 & 69.5 & 13.9 & 63.2 \\
\hline \multicolumn{10}{|l|}{ First language } \\
\hline Other & 3 & 17.0 & 53.1 & 13.0 & 32.5 & 12.0 & 54.5 & 10.8 & 49.1 \\
\hline English & 37 & 23.4 & 73.1 & 20.0 & 50.0 & 16.1 & 73.2 & 15.1 & 68.6 \\
\hline \multicolumn{10}{|l|}{ Nationality } \\
\hline Other & 4 & 21.8 & 68.1 & 27.8 & 69.5 & 15.5 & 70.5 & 16.5 & 75.0 \\
\hline Australian or NZ & 29 & 22.3 & 69.7 & 16.8 & 42.0 & 14.8 & 67.3 & 13.8 & 62.7 \\
\hline \multicolumn{10}{|l|}{ Previous education } \\
\hline VCE or TAFE & 17 & 23.5 & 73.4 & 19.8 & 49.5 & 16.0 & 72.7 & 15.1 & 68.6 \\
\hline Other & 22 & 22.0 & 68.8 & 19.1 & 47.8 & 15.4 & 70.0 & 14.3 & 65.0 \\
\hline \multicolumn{10}{|c|}{ Completion - previous education } \\
\hline Pre - 2000 & 16 & 23.6 & 73.8 & 20.6 & 51.5 & 16.7 & 75.9 & 15.7 & 71.4 \\
\hline $2000-2010$ & 22 & 22.2 & 69.4 & 18.1 & 45.3 & 15.0 & 68.2 & 13.7 & 62.3 \\
\hline \multicolumn{10}{|l|}{ Family situation } \\
\hline No dependents & 24 & 23.2 & 72.5 & 17.7 & 44.3 & 15.2 & 69.1 & 14.0 & 63.6 \\
\hline Dependents & 15 & 22.1 & 69.1 & 21.3 & 53.3 & 16.5 & 75.0 & 15.5 & 70.5 \\
\hline \multicolumn{10}{|l|}{ Employment } \\
\hline No employment & 11 & 22.6 & 70.6 & 20.0 & 50.0 & 14.7 & 66.8 & 15.0 & 68.2 \\
\hline Employment & 28 & 22.8 & 71.3 & 19.1 & 47.8 & 16.1 & 73.2 & 14.5 & 65.9 \\
\hline \multicolumn{10}{|l|}{ Enrolment category } \\
\hline Part-time & 15 & 23.6 & 73.8 & 18.8 & 47.0 & 16.7 & 75.9 & 15.3 & 69.5 \\
\hline Full-time & 24 & 22.3 & 69.7 & 19.2 & 48.0 & 15.7 & 71.4 & 14.0 & 63.6 \\
\hline \multicolumn{10}{|l|}{ Enrolled course } \\
\hline Other & 16 & 23.5 & 73.4 & 23.1 & 57.8 & 17.1 & 77.7 & 15.9 & 72.3 \\
\hline Arts & 23 & 22.2 & 69.4 & 16.6 & 41.5 & 14.7 & 66.8 & 13.7 & 62.3 \\
\hline \multicolumn{10}{|l|}{ Payment options } \\
\hline Pays fees as due & 7 & 23.9 & 74.7 & 23.0 & 57.5 & 16.4 & 74.5 & 17.1 & 77.7 \\
\hline Fee deferral & 31 & 22.4 & 70.0 & 18.1 & 45.3 & 15.4 & 70.0 & 13.8 & 62.7 \\
\hline \multicolumn{10}{|l|}{ First preference } \\
\hline Yes & 34 & 23.4 & 73.1 & 17.2 & 43.0 & 15.8 & 71.8 & 13.2 & 60.0 \\
\hline No & 5 & 22.7 & 70.9 & 19.4 & 48.5 & 15.7 & 71.4 & 14.7 & 66.8 \\
\hline
\end{tabular}

M:Mean adjustment subscale score, \%:Percentage mean adjustment subscale score

As a group, the highest mean adjustment score was identified in the Personal Adjustment scale; 15.7 out of 22 (71.4\%), followed closely by Academic Adjustment (71.3\%). In contrast, the mean adjustment score of the group on the Social Adjustment scale was much lower at 19.3 out of a possible 40 (48.3\%). Students' mean adjustment scores on Attachment were higher than on Social Adjustment, but lower than on the other two scales (66.4\%).

Although differences were noted between the scores of students within each of the 12 characteristic groups, no significant differences were indicated on any of the four scales of adjustment; however, scale scores in Social Adjustment and Attachment were lowest for most characteristic groups. Figure 1 to Figure 4 present a graphical representation of the mean adjustment scale scores, differentiated for the 12 demographic groups (Table 3). 


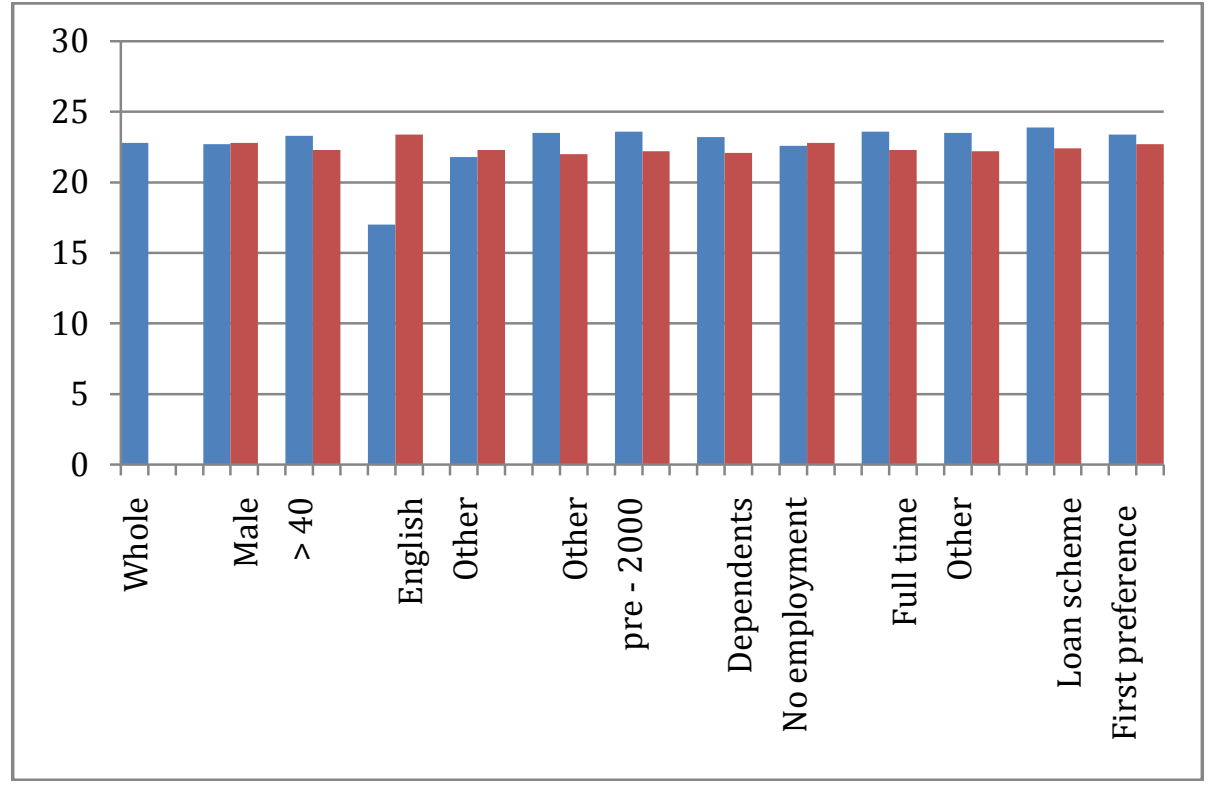

Figure 1 Mean adjustment scores for Academic Adjustment differentiated according to demographic groups

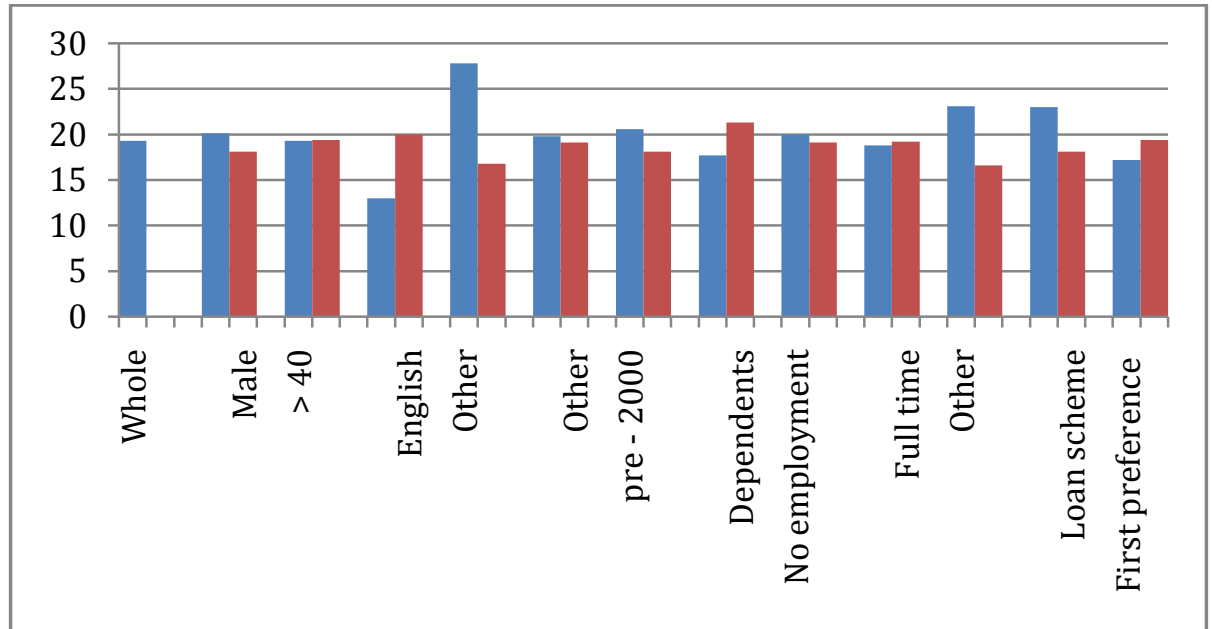

Figure 2 Mean adjustment scores for Social Adjustment differentiated according to demographic groups

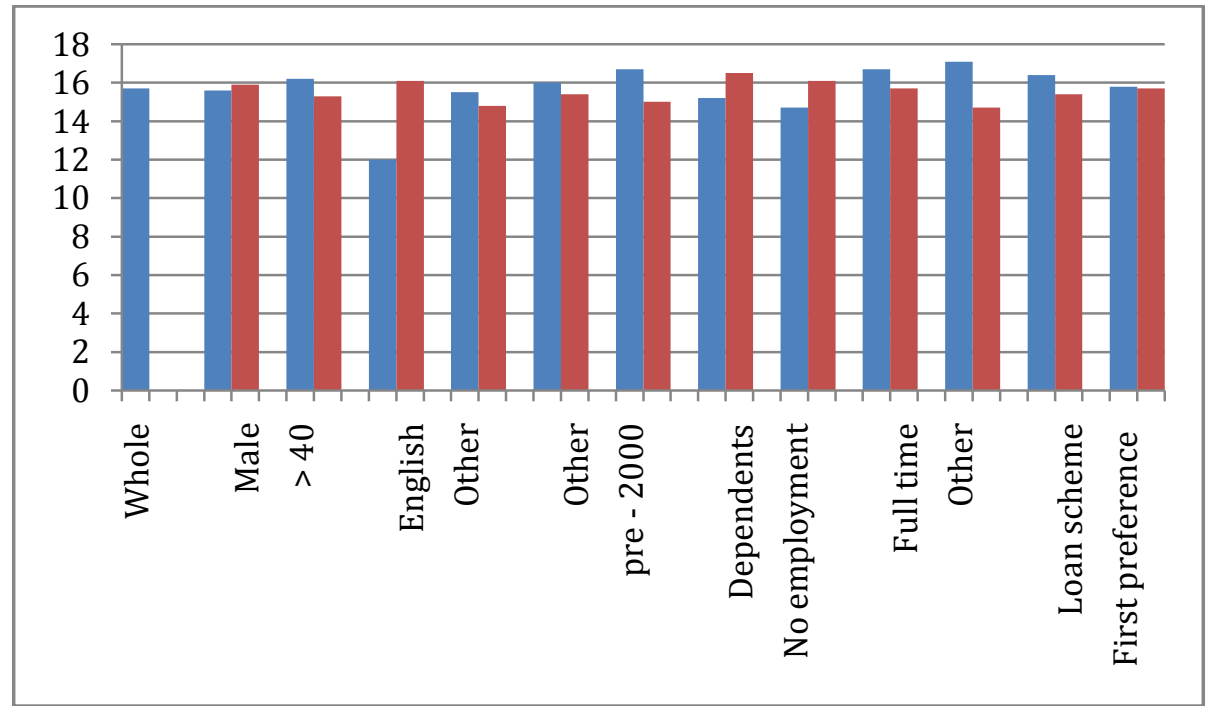

Figure 3Mean adjustment scores for Personal Adjustment differentiated according to demographic groups 


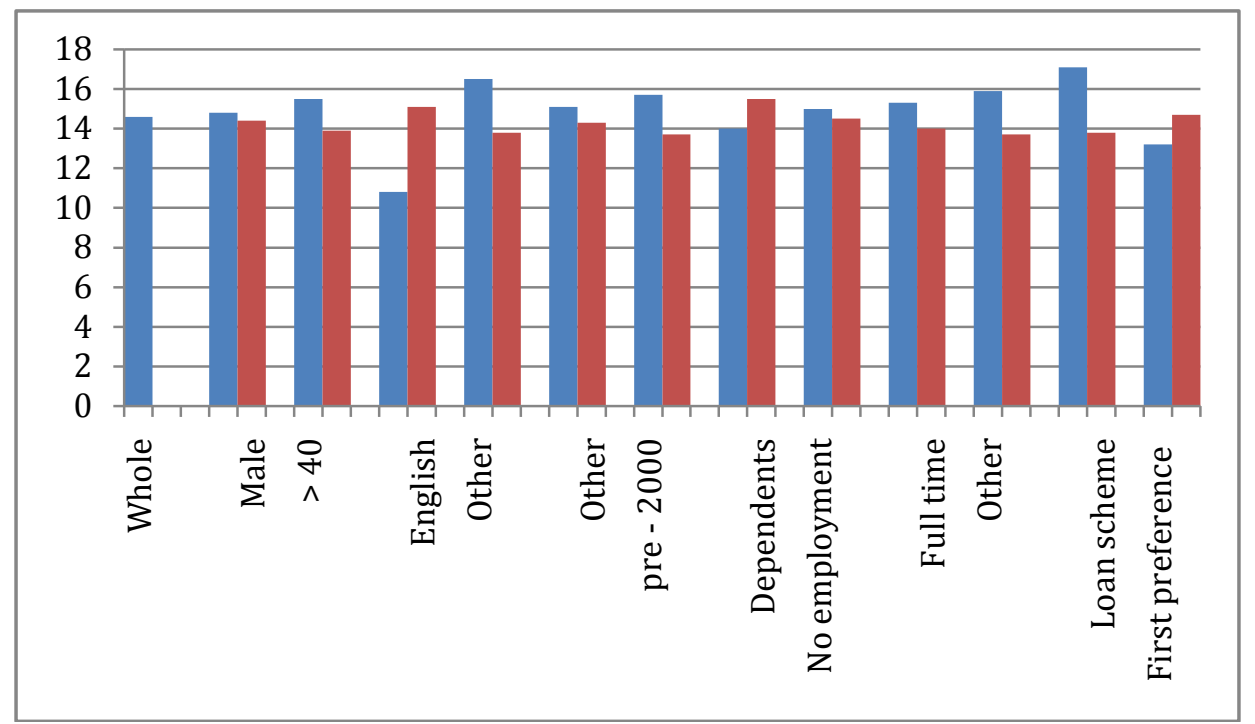

Figure 4 Mean adjustment scores for Attachment differentiated according to demographic groups Associations between the four scales of adjustment and demographic groups

Scale scores were calculated by adding the subscale scores in each of the four scales. In Academic Adjustment, the scale score was calculated through the addition of the subscale scores of Application, Performance and Environment. The subscale of Motivation was excluded from the scale score of Academic Adjustment due to its lack of significant associations within the scale. Spearman bivariate rank correlation analyses were used to determine the strength of associations between the demographic groups and the four scale scores (Table 4).

Table 4 Correlations between the four scale scores and demographic groups

\begin{tabular}{lclll}
\hline $\begin{array}{l}\text { Characteristic } \\
\text { Adjustment }\end{array}$ & Academic & $\begin{array}{l}\text { Social } \\
\text { Adjustment }\end{array}$ & $\begin{array}{l}\text { Personal } \\
\text { Adjustment }\end{array}$ & Attachment \\
\hline Gender & 0.090 & -0.139 & 0.065 & 0.036 \\
Age group & 0.000 & 0.000 & -0.092 & -0.236 \\
First language & 0.239 & $0.338^{*}$ & $0.327^{*}$ & $0.384^{*}$ \\
Nationality & 0.215 & -0.303 & -0.069 & -0.191 \\
Previous education & 0.090 & 0.151 & 0.054 & 0.146 \\
Period of completion & -0.039 & -0.095 & -0.224 & -0.235 \\
of previous education & & & & \\
Family situation & -0.230 & 0.107 & 0.119 & 0.095 \\
Employment situation & -0.124 & -0.053 & 0.029 & -0.049 \\
Enrolment category & 0.306 & 0.195 & 0.129 & 0.007 \\
Enrolled course & 0.035 & -0.299 & -0.103 & -0.170 \\
Payment options & -0.040 & -0.115 & 0.012 & -0.109 \\
First preference offer & -0.065 & 0.051 & 0.051 & 0.130 \\
\hline
\end{tabular}

$* \mathrm{p}<0.05$ Gender $0=$ female, Age group $0=>40$, First language $0=$ other, Nationality $0=$ other, Previous education $0=\mathrm{VCE}+\mathrm{TAFE}$, Period of completion of previous education $0=<2000$, Family situation $0=$ no dependents, Employment situation $0=$ no employment, Enrolment situation $0=$ part-time, Enrolled course $0=$ not Arts, Payment options $0=$ pays fees as due, First preference offer $0=$ no

No significant differences were identified between the demographic groups and the four scale scores, except for the group involving first language spoken. The scores of students with English as their first language were associated positively and significantly with all scales except Academic Adjustment.

\section{Measuring students' overall adjustment}

To support the measure of an overall score of adjustment for participants in the study, associations were determined between the four scales of adjustment using bivariate Spearman two-tailed correlation analyses (Appendix 2). Scale scores were calculated by adding the subscale scores in each of the four scales. 
In Academic Adjustment, the scale score was calculated through the addition of three of the four subscale scores; Application, Performance and Environment. The subscale of Academic Motivation was excluded from the scale score of Academic Adjustment due to its lack of significant associations within the scale.

Apart from the lack of association between the scales of Academic Adjustment and Social Adjustment, associations between the four scales were significant. The significance of the association between the scales of Attachment and Social Adjustment was not unexpected $(p<0.01)$, since seven of the 11 items in the Attachment scale were also included in the Social Adjustment scale. A measure of student adjustment to university, an Overall Index of Adjustment (OIA) was obtained by taking the total of the three scale scores; Social Adjustment, Personal Adjustment and Attachment, established from participant responses to the items on the survey questionnaire and associations within and between the four scales of adjustment. Calculation of an Overall Index of Adjustment for different background and demographic groups enabled comparisons to be made between the different demographic groupings (Table 5).

Table 5Overall Index of Adjustment for the whole group and differentiated according to demographic groups

\begin{tabular}{|c|c|c|c|}
\hline Characteristic & Category & $N$ & $\begin{array}{l}\text { Overall } \\
\text { Index of Adjustment } \\
(84)\end{array}$ \\
\hline & & & Mean \\
\hline Whole group & & 40 & 49.7 \\
\hline \multirow[t]{2}{*}{ Gender } & Female & 25 & 50.5 \\
\hline & Male & 15 & 48.4 \\
\hline \multirow[t]{2}{*}{ Age group } & $>40$ & 18 & 50.9 \\
\hline & $23-40$ & 22 & 48.6 \\
\hline First & Other & 3 & 35.8 \\
\hline Language & English & 37 & 51.2 \\
\hline \multirow[t]{2}{*}{ Nationality } & Other & 4 & 59.8 \\
\hline & Aust. or NZ & 29 & 45.6 \\
\hline Previous & VCE or TAFE & 17 & 50.9 \\
\hline education & Other & 22 & 48.8 \\
\hline $\begin{array}{l}\text { Period } \\
\text { completion }\end{array}$ & pre -2000 & 16 & 52.9 \\
\hline previous education & $2000-2010$ & 22 & 46.8 \\
\hline \multirow[t]{2}{*}{ Family situation } & No dependents & 24 & 46.9 \\
\hline & Dependents & 15 & 53.3 \\
\hline \multirow[t]{2}{*}{ Employment } & No employment & 11 & 49.7 \\
\hline & Employment & 28 & 49.6 \\
\hline \multirow[t]{2}{*}{ Enrolment category } & Part-time & 15 & 48.9 \\
\hline & Full-time & 24 & 50.1 \\
\hline \multirow[t]{2}{*}{ Enrolled course } & Other & 16 & 56.1 \\
\hline & Arts & 23 & 44.9 \\
\hline \multirow[t]{2}{*}{ Payment options } & Pays fees as due & 7 & 56.6 \\
\hline & Fee deferral & 31 & 47.4 \\
\hline preference & Yes & 34 & 49.8 \\
\hline offer & No & 5 & 46.2 \\
\hline
\end{tabular}

The mean Overall Index of Adjustment for the group of 40 students was 49.7 out of a possible score of 84 . The highest adjustment score (59.8) was obtained by the group of four students whose nationality was other than Australian or New Zealander. The second highest Overall Index of Adjustment was recorded by students who paid their university fees as they were due (56.6), followed by students enrolled in courses other than Arts (56.1). The three mature-age students who spoke a first language other than English revealed the lowest adjustment score (35.8). 
Other scores that were at the lower end of the range included the scores of students enrolled in an undergraduate Arts course (44.9), students with Australian or New Zealand nationality (45.6) and students not in their first preference course (46.2). The Overall Index of Adjustment mean scores for the whole group and differentiated for the 12 demographic groupings, provided in Table 5, are presented graphically in Figure 5.

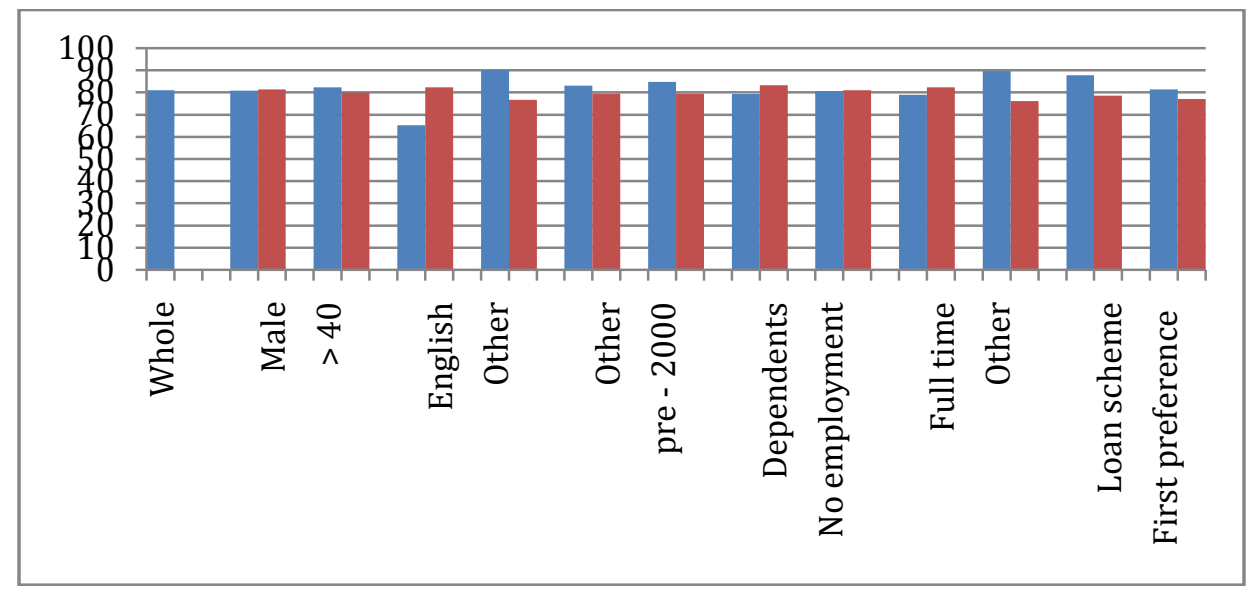

Figure 5 Overall Index of Adjustment differentiated according to demographic groups

\section{Associations between the overall index of adjustment and demographic groups}

To determine the strength of the associations between the 12 demographic groups and the Overall Index of Adjustment, calculated from the addition of the three scales; Social Adjustment, Personal Adjustment and Attachment, Spearman bivariate rank correlation analyses were calculated (Table 6).

Table 6Correlations between the Overall Index of Adjustment and demographic groups

\begin{tabular}{lc}
\hline Characteristic & Overall Index of Adjustment \\
\hline Gender & 0.060 \\
Age group & -0.092 \\
First language & $0.387^{*}$ \\
Nationality & -0.259 \\
Previous education & 0.150 \\
Period of completion of previous & -0.202 \\
education & \\
Family situation & 0.171 \\
Employment situation & -0.044 \\
Enrolment category & 0.168 \\
Enrolled course & -0.242 \\
Payment options & -0.068 \\
First preference offer & 0.061 \\
$* \mathrm{p}<0.05$ &
\end{tabular}

The correlation between first language spoken and the Overall Index of Adjustment was significant and positive ( $\mathrm{p}<0.05$ ), indicating that speaking English as a first language is associated with high scores on overall adjustment. This was the only significant correlation between the 12 characteristics and the Overall Index of Adjustment.

\section{Discussion}

This study sought to determine the demographic factors which affect student adjustment to university. Although the results were generally non-significant, the findings suggest that some groups of students adjust better than others. The group of students who spoke English as their first language had positive and significant associations with the scales of Social Adjustment, Personal Adjustment and Attachment and with the calculated Overall Index of Adjustment (OIA). This group was also identified as having the highest OIA. The lowest score on the OIA was shown by the group of students who spoke a first language other than English. 
Students who are not fluent in English can have difficulties keeping up with the pace of lectures, accessing university support, communicating in tutorials and participating in social activities, thus affecting both their academic and social adjustment (McInnis \& James, 1995; Huon \& Sankey, 2000; Andrade, 2006). Difficulties making the adjustment academically and socially, can lead to a reduction of self-confidence (Sherry, et al.,2010) and affect students' personal adjustment (Yang, et al., 2006).

A consideration of gender did not reveal statistically significant associations with the Overall Index of Adjustment; however, male students showed higher adjustment scores than female students in Academic and Personal Adjustment, while female students showed higher scores in the scales of Social Adjustment and Attachment to university. Female students had a higher Overall Index of Adjustment than male students.

The mean Overall Index of Adjustment for students who were aged over 40 years was higher than for the students who were in the age group 23 - 40 years. Similarly, adjustment scores for students aged over 40 years were higher than for those students aged between 23 and 40 years on all scales except Social Adjustment. No statistically significant relationships were indicated between age (within the status 'mature-age') and the Overall Index of Adjustment.

Over 17 percent of the students who responded to the survey questionnaire paid their fees as they were due while nearly 80 percent indicated they were using a fee deferral/loan scheme. Association between payment options and adjustment was not found to be statistically significant at the 0.05 level; however, the students who paid their fees as they were due, showed the second highest score on the Overall Index of Adjustment of the 12 demographic groups.

These students also had higher scores on all four scales of adjustment; Academic, Social, Personal Adjustment and Attachment than the students who were using a fee deferral scheme. This suggests that payment of university fees as they are due may have some effect on university adjustment, possibly due to the motivation and dedication involved in making a financial commitment at the time of studying rather than paying the fees some years later. The relationship between fee payment options and university adjustment has not been widely researched in previous studies.

Enrolment in their preferred course has not been extensively used as a variable in previous studies of transition, yet it appears related to student's overall adjustment to university. Students enrolled in their preferred course have been found to show greater satisfaction with their university experience than those not in their first preference course(Mclnnis\& James, 1999, 2004). Although no statistically significant association was identified between course preference and adjustment, students enrolled in their first preference course showed a higher Overall Index of Adjustment and higher scores on the Academic and Personal Adjustment scales than students not enrolled in their first preference course.

As previously noted, 70 percent of the students who participated in the survey questionnaire were employed in paid work; 60 percent in part-time employment and 10 percent in full-time employment. The combination of parttime employment and full-time enrolment was the most common with 37.5 percent of participants in this situation. No statistically significant differences were found between any combination of employment and enrolment and the Overall Index of Adjustment; however, students with part-time enrolment received the highest score on Personal Adjustment, suggesting that part-time enrolment is an appropriate choice in order to maintain a suitable work/life/study balance.

The distinctions between the personal background and demographic groups relating to students' level of previous education and period of completion of previous education did not reveal statistically significant differences with the Overall Index of Adjustment or with the four scales of adjustment, yet the 17 students with a background of the Victorian Certificate of Education (VCE) or Technical and Further Education (TAFE) had higher scores on all four scales and the Overall Index of Adjustment. Similarly, the 16 students who completed their previous education prior to the year 2000 showed higher scores than students who completed their previous education post2000, suggesting entering university directly from school or an alternative pre-requisite course as an older student, does not necessarily promote a positive experience of adjustment for mature-age students. 


\section{Conclusion}

The demographics of the participants in this study provide some evidence that a high proportion of mature-age students enroll in university with a non-traditional entry course and that some have not pursued academic study at secondary level for many years. Fifty-five percent of the participants had entered university without the usual pathway for university entry in Victoria, and 40 percent had not completed their previous education within the preceding ten years. It is important that universities make provision for students with different educational backgrounds, to ensure that all students are supported in their transition and make a positive adjustment to university.

The main limitation of the study was the size of the sample $(N=40)$. This was a result of the relatively small number of mature-age students enrolled at the university and issues preventing individual approaches by the researcher to mature-age students. A larger sample size would ensure the findings were more representative of the population of mature-age students at the university and increase the likelihood of obtaining results which are statistically significant. Extending the study to other universities and tertiary colleges would provide a wider range of perspectives and a more representative sample, providing results which are more transferable to the broader community. The relationship between demographic characteristics such as gender, enrolment category, fee payment options, entry into first preference courses and enrolled course, with university adjustment, warrants further investigation to determine if the trends identified in this study, although not statistically significant, are apparent in studies involving larger numbers of students.

To fully understand the transition and adjustment of all undergraduate students to university, an appreciation of the experiences of under-represented demographic groups within the first-year cohort must be examined. Matureage students need to be encouraged to enroll and persist at university. It is essential that students, who make the decision to commence their first university degree at a later life stage, have a smooth transition and make a positive adjustment to university.

\section{References}

Anderson, G., Benjamin, D.,\& Fuss, M. (1994).The Determinants of Success in University Introductory Economics Courses.The Journal of Economic Education, 25(2), 99-119.

Andrade, M. (2006). International students in English-speaking universities. Adjustment factors.Journal of Research in International Education,5(2), 131-154.

Ayres, R.,\& Guilfoyle, A. (2009). Experiences of mature-age female students studying psychology: Implications for the university learning environment, In Teaching and Learning for global graduates. Paper presented at the $18^{\text {th }}$ Annual Teaching Learning Forum, Perth, Australia.

Baker, R., \&Siryk, B. (1989, 1999). Student Adaptation to College Questionnaire manual. Los Angeles: Western Psychological Services.

Bird, J.,\& Morgan, C. (2003).Adults contemplating University Study at a Distance: Issues, themes and concerns. Southern Cross University, Australia (2003). Retrievedfrom www.irrodl.org/index.php/irrodl/article/ view/130/210

Buote, V., Pancer, S., Pratt, M., Adams, G., Birnie-Lefcovitch, S., Polivy, J.,\&Wintre, M. (2007). The Importance of friends. Friendship and Adjustment Among $1^{\text {st }}$-Year University Students.Journal of Adolescent Research, 22(6), 665-689.

Carney-Crompton, S.,\& Tan, J. (2002). Support Systems, Psychological Functioning, and Academic Performance of Non-traditional Female Students.Adult Education Quarterly, 52(2), 140-154.

Conley, D. (2007). EPIC Educational Policy Improvement Centre: Toward a More Comprehensive Conception of College Readiness, Prepared for the Bill and Melinda Gates Foundation, Eugene, OR.

Cook, A.,\&Leckey, J. (1999). Do Expectations Meet Reality? A survey of changes in first year student opinion.Journal of Further and Higher Education, 23(2), 157-171.

Cushman, P. (2004). Juggling Priorities: A Comparison of Young and Mature-age Students' use of time during their first semester of teacher education. Waikako Journal of Education, 10, 1-16.

Darlaston-Jones, D. Cohen, L., Haunold, S., Pike, L., Young, A.,\& Drew, N. (2003). The retention and persistence support (RAPS) project: A transition initiative.Issues in Educational Research, 13: 1-12. Retrieved from http://www.iier.org.au/iier13/darlaston-jones2.html 
Dawborn-Gundlach, L. M. (2015). The experience of transition and adjustment for mature-age, undergraduate students in their first year of university (Doctoral dissertation). Retrieved fromhttps://eds-b-ebscohostcom.ezp.lib.unimelb.edu.au

Dawborn-Gundlach, M., \& Margetts, K. (2018). Measures of the adjustment of mature-age, undergraduate students to university. Journal of Global Education and Research, 1 (2), 84-99. Retrieved from https://scholarcommons.usf.edu/jger/vol1/iss2/2

Educational Transitions and Change Research Group. (2011). Transition to School: Position statement. AlburyWodonga: Research Institute for Professional Practice, Learning and Education, Charles Sturt University, Australia.

Evans, M.,\& Peel, M. (1999). Factors and problems in school and university transition.Higher Education Series: Transition from Secondary to Tertiary: A Performance Study, Report No. 36, 4-6.

Evans, M. (2000). Planning for the transition to tertiary study: a literature review.Journal of Institutional Research, 9(1), 1-12.

Friedlander, L., Reid, G., Shupak, N.,\&Cribbie, R. (2007). Social Support, Self-Esteem, and Stress as Predictors of Adjustment to University Among First-Year Undergraduates.Journal of College Student Development, 48(3), 259-274.

Gall, T., Evans, D. \& Bellerose, S. (2000). Transition to First-Year University: Patterns of Change in Adjustment Across Life Domains and Time.Journal of Social and Clinical Psychology, 19(4), 544-567. University of Western Ontario.

Hellsten, M. (2002). Students in transition: Needs and Experiences of International Students in Australia. Paper presented at the $16^{\text {th }}$ Australian International Education Conference, Hobart, Australia.

Huon, G.,\& Sankey, M. (2000). The transition to university.Understanding differences in success, Sydney, Australia. School of Psychology University of New South Wales.

Kantanis, T. (2000). Transition to university - a holistic approach: A case study of the Monash Transition Program. Paper presented at the $4{ }^{\text {th }}$ Pacific Rim, First Year in Higher Education Conference, Brisbane, Australia.

Kantanis, T. (2002). Same or different: Issues that affect mature-age undergraduate students' transition to university. Paper presented at the $6^{\text {th }}$ Pacific Rim, First Year in Higher Education Conference, Christchurch, New Zealand.

Krause, K., Hartley, R., James, R.,\& McInnis, C. (2005). The first year experience in Australian universities: findings from a decade of national studies. Canberra, Australia.

Lee Dow, K. (2009). Report advising on the development of the Victorian tertiary education plan, December 2009. Retrieved from www.skills.vic.gov.au

McInnis, C.,\& James, R. (1995). First Year on Campus, Canberra: Australian Government Publishing Service. Retrieved from www.dest.gov.au/archive/highered/eippubs/cip98-20/chapter 2

Mclnnis, C. \& James, R. (1999). Adjustment and transition for school-leavers.Higher Education Series: Transition from Secondary to Tertiary: A Performance Study, Report No. 36, 1-4.

McInnis, C., Hartley, R., Polesel, J.,\&Teese, R. (2000). Non-completion in vocational education and training in higher education: a literature review commissioned by the Department of Education, Training and Youth Affairs:Centre for the Study of Higher Education (CSHE),University of Melbourne. Retrieved fromhttp://hdl.voced.edu.au/10707

Newson, C., McDowall, A., \& Saunders, M. (2011). Understanding the support needs of mature students. Retrieved from https://www.surrey.ac.uk/psychology/files/Mature_student_report_2011

Organisation for Economic Co-operation and Development (OECD). (2017). Retrieved from https://data.oecd.org/eduatt/enrolment-rate.htm

Pargetter, R., McInnis, C., James, R., Evans, M., Peel, M.,\& Dobson, I. (1998). Transition from Secondary to Tertiary: A Performance Study. Department of Education, Training and Youth Affairs. Retrieved from www.dest.gov.au/archive/highered/eippubs/eip98-20/conc

Richardson, J. (1995). Mature students in higher education: II. An investigation of approaches to studying and academic performance.Studies in Higher Education, 20(1), 5-17.

Sherry, M., Thomas, P.,\&Chui, W. (2010). International students: a vulnerable student population.The Journal of Higher Education, 60(1), 33-46. 
Tinto, V. (1975). Dropouts from higher education: A theoretical synthesis of recent research.Review of Educational Research, 45, 89-125.

Tinto, V. (1995, July). Keynote Address presented at the Inaugural Pan Pacific First Year Experience Conference, Brisbane, Australia.

Tinto, V. (2005). Taking student success seriously: Rethinking the first year of college. Chicago: University of Chicago Press.

Yang, R., Noels, K.,\&Saumure, K. (2006). Multiple routes to cross-cultural adaptation for international students: mapping the paths between self-construals, English language, confidence and adjustment.International Journal of Intercultural Relations, 30(4), 487-506.

Yau, H., Sun, H.,\& Cheng, A. (2012). Adjusting to university: The Hong Kong Experience.Journal of Higher Education Policy and Management, 3(1), 15-27.

\section{Appendices}

\section{Appendix 1}

Appendix 1 presents each of the four scales of adjustment, a description of the ten subscaleswithin the scales and the related item numbers on the modified SACQ survey questionnaire.

\section{Adjustment scales and subscales}

\begin{tabular}{|c|c|c|c|}
\hline Scale & Subscale & Description & Item Numbers \\
\hline \multicolumn{2}{|c|}{ Academic Adjustment (AA) } & \multicolumn{2}{|c|}{ Contains 21 items in four subscales } \\
\hline & Motivation (AAM) & $\begin{array}{l}\text { Attitudes towards academic } \\
\text { goals, motivation and purpose }\end{array}$ & $5,13,14,27,34$ \\
\hline & Application (AAA) & $\begin{array}{l}\text { The extent to which the } \\
\text { motivation is translated into } \\
\text { effort }\end{array}$ & 3,24 \\
\hline & Performance(AAP) & The success of the application & $\begin{array}{l}6,9,15,19,21,29,46 \\
54,55\end{array}$ \\
\hline & $\begin{array}{l}\text { Environment } \\
\text { (AAE) }\end{array}$ & $\begin{array}{l}\text { Satisfaction with the } \\
\text { environment }\end{array}$ & $17,23,31,38,42$ \\
\hline \multicolumn{2}{|c|}{ Social Adjustment (SA) } & \multicolumn{2}{|c|}{ Contains 20 items in four subscales } \\
\hline & General (SAG) & $\begin{array}{l}\text { Extent and success of social } \\
\text { activities }\end{array}$ & $1,7,8,12,18,25,41$ \\
\hline & Other People (SAP) & $\begin{array}{l}\text { Relationships with other } \\
\text { people at university }\end{array}$ & $\begin{array}{l}4,10,22,39,48,49 \\
50,51\end{array}$ \\
\hline & Nostalgia (SAN) & $\begin{array}{l}\text { Social relocation and } \\
\text { homesickness }\end{array}$ & 28,33 \\
\hline & Environment (SAE) & $\begin{array}{l}\text { Satisfaction with the social } \\
\text { aspects of the university }\end{array}$ & $11,16,47$ \\
\hline \multicolumn{2}{|c|}{ PersonalAdjustment (PA) } & \multicolumn{2}{|c|}{ Contains 11 items in two subscales } \\
\hline & $\begin{array}{l}\text { Psychological } \\
\text { (PAPs) }\end{array}$ & Psychological well-being & $\begin{array}{l}2,26,30,40,43,53, \\
54,\end{array}$ \\
\hline & Physical (PAPh) & Physical well-being & $20,32,44,45$ \\
\hline \multirow{2}{*}{\multicolumn{2}{|c|}{ Attachment (A) }} & $\begin{array}{l}\text { Contains } 11 \text { items in one } \\
\text { scale }\end{array}$ & \\
\hline & & $\begin{array}{l}\text { Degree of satisfaction with the } \\
\text { university }\end{array}$ & $\begin{array}{l}1,4,11,17,22,33,35, \\
36,37,41,50\end{array}$ \\
\hline
\end{tabular}

The Student Adaptation to College Questionnaire(Baker \&Siryk, 1989, 1999) 


\section{Appendix 2}

Appendix 2 presents the association within and between the four scales of adjustment, calculated using Spearman bivariate rank correlation analyses.

\section{Correlations within and between the four scales of adjustment}

\begin{tabular}{|c|c|c|c|c|c|c|c|c|c|c|c|c|}
\hline \multicolumn{4}{|c|}{ Academic Adjustment (AA) } & \multicolumn{8}{|c|}{ Social Adjustment (SA) Personal Adjustment (PA) Attachment (A) } & \\
\hline & AAA & AAP & $\mathrm{AAE}$ & AASAG & SAP $\quad$ SA & SAN & SAE $\quad \mathbf{S}$ & A & PAPs & PAPhPA & $\mathbf{A}$ & \\
\hline AAM & .092 & .283 & .147 & -.049 & -.029 & .229 & -.021 & & .054 & .226 & & .205 \\
\hline AAA & & $.386^{*}$ & $.495^{* *}$ & .047 & -.070 & -.111 & .284 & & $.389 *$ & .218 & & .102 \\
\hline AAP & & & .204 & .078 & .203 & .114 & .302 & & $.688 * *$ & $.457 * *$ & & .165 \\
\hline AAE & & & & .190 & .196 & .130 & $.486 * *$ & & $.420 * *$ & $.326^{*}$ & & $.521 * *$ \\
\hline $\mathbf{A A}$ & & & & .028 & .125 & .138 & $.357 *$ & .207 & $.640 * *$ & $.447 * *$ & $.626^{* *}$ & $.317^{*}$ \\
\hline SAG & & & & & $.703 * *$ & $* \quad .334 *$ & $.584 * *$ & & $.439 * *$ & .280 & & $.700^{* *}$ \\
\hline SAP & & & & & & .307 & $.633 * *$ & & $.493^{* *}$ & $.404 * *$ & & $.696^{* *}$ \\
\hline SAN & & & & & & & $.334 *$ & & .292 & .281 & & $.601 * *$ \\
\hline SAE & & & & & & & & & $.644 * *$ & $.445^{* *} *$ & & $.718 * *$ \\
\hline SA & & & & & & & & & $.595 * *$ & $.437 * *$ & $.592 * *$ & $.789 * *$ \\
\hline PAPs & & & & & & & & & & & $.614 * *$ & $.531 * *$ \\
\hline $\mathrm{PAPh}$ & & & & & & & & & & & & $.537 * *$ \\
\hline PA & & & & & & & & & & & & $.593 * *$ \\
\hline
\end{tabular}

** $\mathrm{p}<0.01 \quad * \mathrm{p}<0.05$

AAM Motivation, AAA Application, AAP Performance, AAE Environment,SAG General, SAP Other People, SAN Nostalgia, SAE Environment,PAPs Psychological, PAPh Physical 